\title{
Gambaran etiologi penyakit ginjal kronik stadium V pada pasien rawat inap di RSUD Dokter Soedarso Pontianak tahun 2017-2018
}

\author{
Kurnia Pralisa ${ }^{1, *}$, Danar Anggrahini Kusuma Dewi ${ }^{2}$, Muhammad In'am Ilmiawan ${ }^{3}$ \\ ${ }^{I}$ Program Studi Kedokteran, Fakultas Kedokteran, Universitas Tanjungpura, Kalimantan Barat, Indonesia \\ ${ }^{2}$ Bagian Ilmu Penyakit Dalam, RSUD dr. Soedarso, Kalimantan Barat, Indonesia \\ ${ }^{3}$ Departemen Biologi dan Patobiologi, Fakultas Kedokteran, Universitas Tanjungpura, Kalimantan Barat, Indonesia \\ *Korespondensi: kurniapralisa@student.untan.ac.id
}

\begin{abstract}
Abstrak
Latar belakang: Penyakit ginjal kronik stadium V merupakan tahap terminal penyakit ginjal kronik yang ditandai dengan penurunan fungsi ginjal ireversibel dan diperlukan terapi pengganti ginjal berupa hemodialisis, dialisis peritoneal, atau transplantasi ginjal. Data RISKESDAS tahun 2013 menunjukkan prevalensi PGK di Kalimantan Barat mencapai 0,20\% yang kemudian meningkat menjadi 0,42\% pada tahun 2018. Prevalensi kasus PGK stadium V di Kalimantan Barat terus meningkat sehingga diperlukan penelitian mengenai etiologi PGK di RSUD dr. Soedarso yang merupakan salah satu rumah sakit umum yang terletak di kota Pontianak dan merupakan rumah sakit rujukan yang memiliki layanan unggulan hemodialisis. Penelitian ini bertujuan untuk mengetahui gambaran etiologi penyakit ginjal kronik stadium V pada pasien rawat inap di RSUD Dokter Soedarso Pontianak. Metode: Penelitian ini merupakan studi deskriptif dengan pendekatan retrospektif. Sampel penelitian adalah 86 penderita penyakit ginjal kronik stadium $\mathrm{V}$ yang menjalani rawat inap. Hasil: Etiologi PGK stadium V terbanyak yaitu hipertensi (64\%), nefropati diabetik (27\%), kemudian infeksi saluran kemih (2\%), obstruksi saluran kemih (3,5\%), dan kista ginjal (3,5\%). Kesimpulan: Etiologi PGK stadium V pada pasien rawat inap di RSUD Dokter soedarso tahun 2017-2018 adalah hipertensi, nefropati diabetik, obstruksi saluran kemih, infeksi saluran kemih dan penyakit polikistik ginjal dengan prevalensi etiologi terbanyak yaitu hipertensi dan terbanyak kedua yaitu nefropati diabetik.
\end{abstract}

Kata kunci: penyakit ginjal kronik, etiologi penyakit ginjal kronik stadium V

\section{Etiologies of stage $\mathbf{V}$ chronic kidney diseases among hospitalized patients at Doctor Soedarso Hospital in Pontianak in 2017-2018}

\begin{abstract}
Background: Stage V chronic kidney disease is a terminal stage of chronic kidney disease, characterized by an irreversible decline in kidney function, and renal replacement therapy in the form of hemodialysis, peritoneal dialysis, or kidney transplantation is required. Data from RISKESDAS in 2013 showed the prevalence of CKD in West Kalimantan reached $0.20 \%$, which increased to $0.42 \%$ in $2018 .^{4}$ The prevalence of CKD stage V cases in West Kalimantan is increasing every year so that research on the etiology of CKD is needed to at dr. Soedarso Hospital as one of the public hospitals located in Pontianak, which serves as a referral hospital with hemodialysis services in West Kalimantan. This study aims to determine the etiologies of stage $\mathrm{V}$ chronic kidney disease among hospitalized patients at Soedarso Hospital in Pontianak. Methods: This was a descriptive study with a retrospective approach. Eighty-six patients with stage V chronic kidney disease who were hospitalized were included in the study. Results: The most common etiologies of CKD stage V were hypertension (64\%), diabetic nephropathy $(27 \%)$, urinary tract infection (2\%), urinary tract obstruction $(3.5 \%)$, and kidney cysts $(3.5 \%)$. Conclusions: The etiologies of CKD stage V among hospitalized patients at RSUD dr. Soedarso 2017-2018 are hypertension, diabetic nephropathy, urinary tract obstruction, urinary tract infection, and polycystic kidney disease. Hypertension and diabetic nephropathy are the most prevalent.
\end{abstract}

Keywords: chronic kidney disease, etiology of stage V chronic kidney disease 


\section{Pendahuluan}

Penyakit ginjal kronik adalah suatu proses patofisiologis yang mengakibatkan kerusakan fungsi ginjal yang progresif, berupa kelainan struktural dan fungsional dengan atau tanpa penurunan laju filtrasi glomerulus (LFG) yaitu kurang dari $60 \mathrm{ml} / \mathrm{menit} /$ $1,73 \mathrm{~m}^{2}$ selama lebih dari tiga bulan. Penyakit ginjal kronik pada stadium $\mathrm{V}$ ditetapkan sebagai chronic kidney failure (CKF) yang merupakan tahap terminal penyakit ginjal kronik, ditandai dengan penurunan fungsi ginjal yang ireversibel dengan LFG kurang dari $15 \mathrm{ml} /$ menit/ $1,73 \mathrm{~m}^{2}$ dan diperlukan terapi pengganti ginjal berupa hemodialisis, dialisis peritoneal, atau transplantasi ginjal. ${ }^{1}$ Pasien ESRD (End-Stage Renal Disease) di dunia berdasarkan laporan tahunan Fresenius Medical Care berjumlah 2.786.000 penderita pada tahun 2011, 3.018.860 penderita pada tahun 2012, dan 3.200.000 penderita pada tahun 2013. Sekitar $1,5 \%$ dari pasien PGK derajat III dan IV akan berlanjut menjadi derajat $\mathrm{V}$ atau PGK tahap akhir (gagal ginjal) per-tahunnya. ${ }^{2}$

Data Riskesdas menunjukkan pada tahun 2013 prevalensi PGK berdasarkan diagnosis dokter di Indonesia sebesar 499.800 penderita $(0,2 \%)$. Pada tahun 2018, prevalensi PGK di Indonesia meningkat menjadi $0,38 \%$ dengan prevalensi tertinggi terdapat di Kalimantan Utara, yaitu 0,68\% dan tertinggi kedua di Maluku Utara, yaitu $0,56 \%$, sedangkan di Kalimantan Barat mencapai 0,42\%.

Prevalensi penderita ginjal kronik stadium V berdasarkan Perkumpulan Nefrologi Indonesia (PERNEFRI) pada tahun 2016 adalah sebanyak 16.587 penderita dengan etiologi terbanyak yaitu nefropati diabetik dengan prevalensi sebanyak 8573 penderita (52\%), dan terbanyak kedua adalah hipertensi dengan prevalensi 3994 penderita (24\%). ${ }^{5}$ Prevalensi penderita PGK mengalami peningkatan setiap tahunnya. Perbedaan etnis, genetik, pola hidup, kebiasaan dan tingkat pengetahuan penduduk Indonesia dapat mempengaruhi perbedaan prevalensi penderita PGK pada setiap daerah. ${ }^{4}$

Dari hasil studi pendahuluan pada tahun 2017, diketahui prevalensi pasien PGK stadium $\mathrm{V}$ yang dirawat inap di RSUD Dokter Soedarso Pontianak berjumlah 343 pasien dengan jumlah pasien meninggal sebanyak 89 pasien. Pada tahun 2018, prevalensi pasien PGK stadium V yang di rawat inap berjumlah 309 pasien, dengan jumlah pasien yang meninggal sebanyak 57 pasien.

Penelitian mengenai etiologi terjadinya PGK di Kalimantan Barat khususnya di Pontianak belum pernah dilakukan, sehingga peneliti tertarik untuk melakukan penelitian mengenai etiologi PGK di sebagai penelitian etiologi PGK pertama di Kalimantan Barat. RSUD Dokter Soedarso merupakan salah satu rumah sakit umum yang terletak di Kota Pontianak dan merupakan rumah sakit rujukan yang memiliki layanan unggulan Hemodialisis di Kalimantan Barat.

\section{Metode}

Penelitian ini merupakan jenis penelitian deskriptif dengan menggunakan pendekatan retrospektif. Populasi target pada penelitian ini adalah penderita penyakit ginjal kronik stadium V. Populasi terjangkau penelitian ini adalah penderita penyakit ginjal kronik stadium $\mathrm{V}$ yang dirawat inap di RSUD Dokter Soedarso Pontianak selama tahun 2017-2018. Sampel penelitian adalah penderita penyakit ginjal kronik stadium $\mathrm{V}$ yang menjalani rawat inap serta memenuhi kriteria inklusi dan eksklusi penelitian. Jumlah sampel berdasarkan perhitungan rumus teori Taro Yamane dan Slovin yaitu sebanyak 86 pasien dari total populasi 599 pasien.

Penelitian ini menggunakan teknik probability sampling dengan jenis simple random sampling. Data yang digunakan dalam penelitian ini adalah data sekunder yang didapat dari rekam medis dan hasil pemeriksaan laboratorium pasien yang diambil di RSUD Dokter Soedarso Pontianak. Analisis data penelitian melalui tahap pengumpulan data, editing, coding, tabulasi yang kemudian data diolah dan disajikan dalam bentuk tabel, grafik, diagram persentase dan distribusi frekuensi.

\section{Hasil}

Selama periode 2 tahun (2017-2018) di RSUD Dokter Soedarso Pontianak ditemukan 599 pasien PGK stadium $V$ yang tercatat di rekam medis rawat inap yang kemudian didapatkan jumlah sampel sebanyak 86 pasien dengan frekuensi kelompok usia terbanyak yaitu usia 46-65 tahun yaitu sebanyak 56 pasien (Gambar 1) 


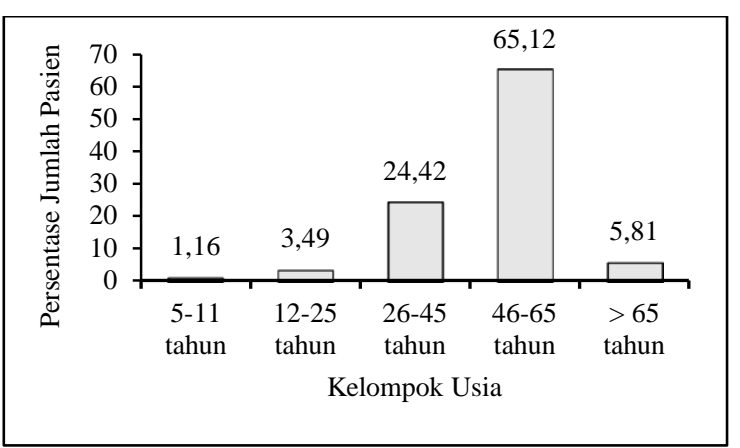

Gambar 1. Persentase penderita PGK stadium V berdasarkan kelompok usia menurut Departemen Kesehatan RI tahun 2009

Lebih banyak pasien berjenis kelamin perempuan daripada laki-laki (Gambar 2). Perbandingan kejadian PGK stadium V antara laki-laki dan perempuan sebesar 1:1,15.

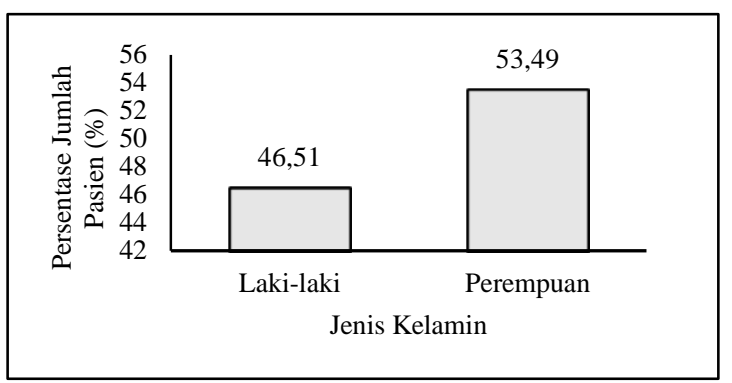

Gambar 2. Persentase penderita PGK stadium V berdasarkan jenis kelamin

Data hasil perhitungan IMT dari berat badan dan tinggi badan pasien didapatkan status gizi terbanyak yaitu normal (Gambar 3). Etiologi PGK stadium V pada pasien rawat inap di RSUD Dokter Soedarso Pontianak meliputi hipertensi, nefropati diabetik, infeksi saluran kemih, obstruksi saluran kemih dan kista ginjal dengan prevalensi terbanyak yaitu hipertensi, kemudian nefropati diabetik (Gambar 4). Pasien dengan etiologi hipertensi berjumlah 55 pasien dengan jenis kelamin perempuan hampir sama dengan yang berjenis kelamin laki-laki, kelompok usia terbanyak 46-65 tahun dan status gizi terbanyak yaitu normal (Tabel 1).

Pasien dengan etiologi nefropati diabetik berjumlah 23 pasien yang lebih banyak berjenis kelamin perempuan, berusia 46-65 tahun dan berstatus gizi normal (Tabel 2).

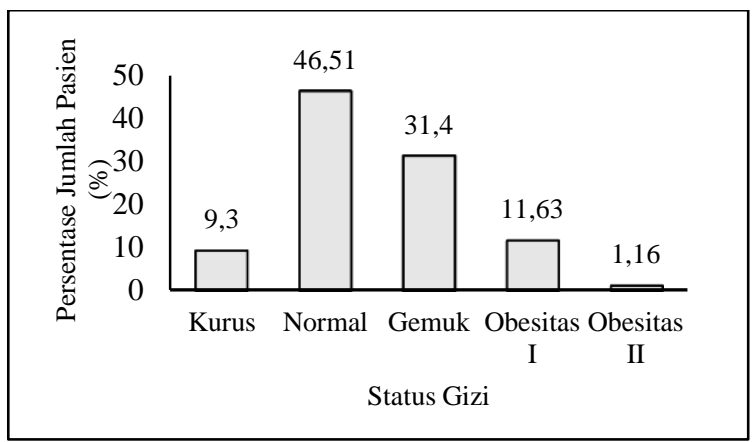

Gambar 3. Persentase penderita PGK stadium V berdasarkan status gizi

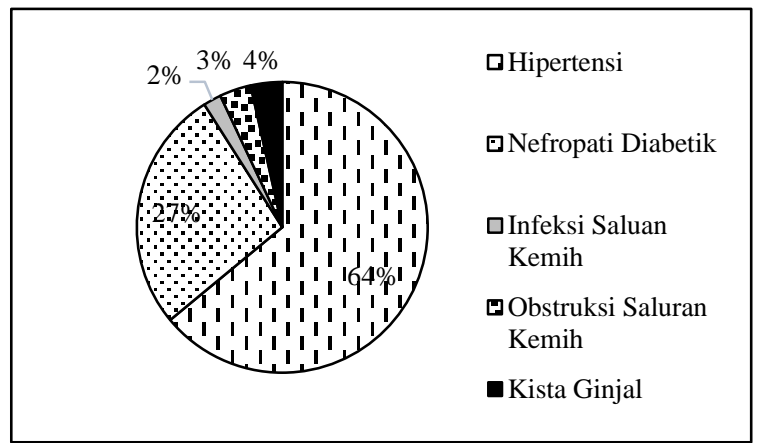

Gambar 4. Persentase Etiologi Pasien PGK Stadium V tahun 2017-2018

Tabel 1. Karakteristik pasien PGK stadium V dengan etiologi hipertensi

\begin{tabular}{lcc}
\hline Karakteristik & $\begin{array}{c}\text { Jumlah } \\
\text { pasien }\end{array}$ & Persentase \\
\hline Jenis kelamin & & \\
$\quad$ Laki-laki & 26 & 47,27 \\
$\quad$ Perempuan & 29 & 52,73 \\
Usia & & \\
12-25 tahun & 3 & 5,45 \\
26-45 tahun & 15 & 27,27 \\
46-65 tahun & 33 & 60 \\
$\quad>65$ tahun & 4 & 7,27 \\
Status Gizi & & \\
Kurus & 3 & 5,45 \\
Normal & 25 & 45,45 \\
Gemuk & 21 & 38,18 \\
$\quad$ Obesitas tingkat I & 6 & 10,91 \\
\hline
\end{tabular}

Tabel 2. Karakteristik pasien PGK stadium V dengan etiologi nefropati diabetik

\begin{tabular}{lcc}
\hline \multicolumn{1}{c}{ Karakteristik } & $\begin{array}{c}\text { Jumlah } \\
\text { Pasien }\end{array}$ & Persentase \\
\hline Jenis Kelamin & & \\
$\quad$ Laki-laki & 9 & 39,13 \\
$\quad$ Perempuan & 14 & 60,87 \\
Usia & & \\
26-45 tahun & 2 & 8,7 \\
46-65 tahun & 21 & 91,3 \\
Status Gizi & & \\
Kurus & 2 & 8,7 \\
Normal & 12 & 52,17 \\
Gemuk & 4 & 17,39 \\
Obesitas tingkat I & 4 & 17,39 \\
Obesitas tingkat II & 1 & $4,35 \%$ \\
\hline
\end{tabular}




\section{Pembahasan}

\section{Karakteristik pasien PGK stadium V}

Penderita PGK stadium V yang menjadi subjek penelitian ini adalah sebanyak 86 pasien dan didapatkan kelompok usia terbanyak adalah 45-65 tahun. Penelitian ini sesuai dengan penelitian di RSUD Al-Ihsan Bandung tahun 2014, yang menemukan usia terbanyak yaitu 45-54 tahun. ${ }^{5}$ Data di Amerika Serikat tahun 2015 menunjukkan bahwa ESRD meningkat pada usia 45-64 tahun. ${ }^{6}$ Setelah usia 40 tahun akan terjadi proses degeneratif yang mengakibatkan terjadinya perubahan anatomi, fisiologi, dan biokimia sehingga menyebabkan penurunan kerja ginjal dan kualitas hidup 1\% setiap tahunnya. ${ }^{7}$

Penyakit ginjal kronik stadium $\mathrm{V}$ pada penelitian lebih banyak diderita perempuan. Hal ini sesuai dengan penelitian di RSUD Al-Ihsan. ${ }^{5}$ Hal ini dikarenakan etiologi terbanyak yaitu hipertensi dan nefropati diabetik yang banyak terjadi pada perempuan.

Status gizi pasien berdasarkan hasil perhitungan IMT sebagian besar berstatus gizi normal. Hal ini sesuai dengan penelitian Ratika ${ }^{8}$ yang mendapatkan pasien PGK stadium V sebagian besar memiliki IMT normal. Pasien PGK stadium V dengan status gizi normal dapat disebabkan oleh keberhasilan edukasi yang diberikan baik oleh dokter, maupun ahli gizi dengan tujuan mencegah malnutrisi yang dapat meningkatkan angka mortalitas pasien dengan terapi dialisis. $^{9}$ Lama menjalani hemodialisis juga berpengaruh terhadap status gizi pasien PGK stadium V. Penelitian Liza menunjukkan bahwa penderita PGK yang menjalani hemodialisis >1 tahun berisiko 1,99 kali dapat mengalami malnutrisi. ${ }^{10}$ Pada pasien dengan status gizi underweight/kurus berhubungan dengan terjadinya pembatasan diet dan asupan makanan yang tidak memadai karena nafsu makan berkurang yang disebabkan adanya gangguan gastrointestinal yaitu anoreksia dan mual dan mengarah pada malnutrisi. ${ }^{11}$

\section{Perbedaan prevalensi faktor etiologi}

Pada hasil penelitian didapatkan etiologi PGK stadium V terbanyak yaitu hipertensi (64\%), nefropati diabetik (27\%), infeksi saluran kemih (2\%), obstruksi saluran kemih (3,5\%), dan kista ginjal $(3,5 \%)$. Hasil penelitian ini sesuai dengan penelitian yang dilakukan di $\mathrm{Afrika}^{12}$ yang juga mendapatkan etiologi terbanyak yaitu hipertensi. Namun pada penelitian di Dubai mendapatkan nefropati diabetik (57\%) menjadi penyebab utama pasien PGK disusul dengan hipertensi $(12,4 \%){ }^{13}$

Prevalensi PGK stadium V yang disebabkan oleh hipertensi lebih tinggi dibandingkan dengan nefropati diabetik dan etiologi lain. Hal ini dapat disebabkan karena nefropati diabetik merupakan komplikasi jangka panjang diabetes mellitus. Nefropati biasanya terjadi dalam waktu 10-15 tahun dan penegakkan diagnosis sering ditegakkan jauh setelah penyakit itu timbul atau diidap oleh pasien. PGK stadium V terjadi pada sekitar 50\% penderita DM tipe II dan diperlukan waktu sekitar 5-10 tahun untuk berprogresif ke PGK stadium V. ${ }^{14}$ Pada penelitian yang telah dilakukan Aulia tahun 2013, onset Diabetes melitus yang paling sering menimbulkan komplikasi nefropati diabetik adalah $5-10$ tahun. $^{15}$

Pada penelitian Adha, didapatkan 50\% pasien dengan PGK stadium $\mathrm{V}$ memiliki lama hipertensi yaitu 1-5 tahun dan 23,3\% memiliki lama hipertensi 6-10 tahun. ${ }^{16}$ Selain itu, berdasarkan hasil RISKESDAS pada tahun 2018, Kalimantan Barat merupakan provinsi dengan prevalensi penderita hipertensi tertinggi ke-5 se-Indonesia setelah Jawa Tengah. ${ }^{17}$ Sedangkan kasus diabetes melitus menempati urutan kedua penemuan kasus setelah hipertensi sebagai penyakit tidak menular tertinggi. ${ }^{18}$ Pasien hipertensi di Indonesia sebanyak 54,4\% rutin minum obat, $32,3 \%$ tidak rutin, $13,3 \%$ tidak minum obat dan sebagian besar masyarakat yang tidak minum obat secara rutin atau tidak minum obat sama sekali dikarenakan sudah merasa sehat. Hipertensi yang tidak terkontrol dan terapi obat yang buruk tentunya beresiko menimbulkan berbagai komplikasi salah satunya PGK stadium V. ${ }^{17}$

\section{Pasien PGK stadium V dengan etiologi obstruksi saluran kemih}

Faktor etiologi lain seperti obstruksi saluran kemih ditemukan pada 3 orang pasien dengan BPH, Tumor Buli dan Nefrolitiasis. Pasien dengan kasus Nefrolitiasis berusia 33 tahun, dan berjenis kelamin laki-laki, hal ini sesuai dengan penelitian Ratu tahun 2016 yang menemukan penderita BSK paling banyak diderita oleh laki-laki. ${ }^{19}$ Androgen akan meningkatkan dan estrogen menurunkan ekskresi oksalat, konsentrasi oksalat plasma, dan endapan kristal kalsium plasma yang akan diperburuk jika memiliki kebiasaan menahan buang air kecil dan 
pola makan yang kurang baik. Selain itu terdapat perbedaan anatomi yaitu saluran kemih pria lebih panjang dibandingkan wanita sehingga lebih banyak kemungkinan substansi pembentuk batu mengendap pada keadaan fisika kimia yang sesuai. ${ }^{20}$ Pada pasien dengan kasus tumor buli/karsinoma kandung kemih berusia 36 tahun dan berjenis kelamin laki-laki. Hal ini sesuai dengan teori yaitu tumor buli kebanyakan terjadi pada jenis kelamin laki-laki dengan perbandingan 3-4 : 1 dengan predileksi pada usia 50-70 tahun. Karsinoma $90 \%$ ditemukan di kandung kemih. $^{21}$ Pasien dengan kasus BPH pada penelitian berusia 77 tahun. Hal ini terkait dengan faktor resiko BPH yang terjadi sekitar $70 \%$ pada laki-laki di atas usia 60 tahun. Pada dasarnya BPH tumbuh pada pria yang menginjak usia tua dan memiliki testis yang masih menghasilkan testosteron. Selain itu, pengaruh hormon estrogen dan prolaktin, pola diet, mikrotrauma, inflamasi, obesitas, dan aktivitas fisik diduga dapat memengaruhi sel prostat untuk menyintesis growth factor, yang selanjutnya berperan dalam memacu terjadinya proliferasi sel kelenjar prostat. ${ }^{22}$

\section{Pasien PGK stadium V dengan etiologi polikistik ginjal}

Pada pasien dengan faktor etiologi polikistik ginjal berjumlah 3 pasien berjenis kelamin laki-laki yang berusia 55 tahun dan 8 tahun serta berjenis kelamin perempuan berusia 34 tahun. Penyakit polikistik ginjal dapat terjadi pada usia dewasa yang disebut sebagai PPGDA yang disebabkan oleh mutasi gen PKD1 dan PKD2, sedangkan penyakit polikistik ginjal juga dapat terjadi pada anak berusia 8 tahun yang disebut Penyakit Polikistik Ginjal Resesif Autosomal (PPGRA) disebabkan oleh mutasi dari gen PKHD1. ${ }^{23}$

\section{Pasien PGK stadium V dengan etiologi infeksi saluran kemih}

Pada pasien dengan faktor etiologi ISK berjumlah 2 orang pasien berjenis kelamin perempuan berusia 39 tahun dan 49 tahun. Hampir semua ISK disebabkan invasi mikroorganisme dari uretra ke dalam kandung kemih bahkan bisa mencapai ginjal (refluks vesikoureter) kemudian dikarenakan panjang uretra wanita lebih pendek dari pada pria yaitu $3-5 \mathrm{~cm}$ dan mudah terkontaminasi feses, sehingga wanita lebih mudah mengalami ISK dibanding pria. $^{24}$

\section{Karakteristik pasien PGK stadium V dengan etiologi hipertensi}

Faktor etiologi PGK stadium V terbanyak pada penelitian yaitu hipertensi dengan persentase $64 \%$. Pasien dengan hipertensi mempunyai risiko mengalami penyakit ginjal kronik 3,2 kali lebih besar. Hipertensi dapat memperberat kerusakan ginjal dengan peningkatan tekanan intraglomerular yang menimbulkan gangguan struktural dan gangguan fungsional pada glomerulus. ${ }^{25}$ Pasien hipertensi pada hasil penelitian lebih sering terjadi pada perempuan, hal ini berbeda dengan hasil penelitian di RSU Haji Medan tahun 2015 dan RSUD Dr. Moewardi tahun 2016 yang mendapatkan jenis kelamin terbanyak adalah laki-laki. ${ }^{26} \mathrm{Hal}$ ini mungkin dikarenakan sebelum usia 45 tahun pria lebih banyak menderita hipertensi dan setelah usia 45 tahun perbandingan antara pria dan wanita yang menderita hipertensi sama namun pada wanita yang obesitas, penggunaan kontrasepsi oral, dan menopause lebih tinggi risiko untuk menderita hipertensi. $^{27}$

Kelompok usia terbanyak pada pasien dengan etiologi hipertensi adalah 46-65 tahun. Hal ini terjadi karena seiring meningkatnya usia, arteri besar kehilangan kelenturannya dan menjadi kaku sehingga darah pada setiap denyut jantung dipaksa untuk melalui pembuluh darah yang sempit daripada biasanya dan menyebabkan naiknya tekanan darah. ${ }^{27}$ Selain itu pada wanita berusia 46-65 tahun terjadi fase menopause, yang menyebabkan perubahan hormonal, yaitu penurunan perbandingan esterogen dan androgen sehingga meningkatkan pelepasan renin, dan memicu peningkatan tekanan darah. ${ }^{7,28}$ Penelitian ini sesuai dengan penelitian di RSU Haji medan tahun 2015 dengan kelompok usia yang tertinggi adalah usia 56-65 tahun $^{26}$ dan di Dubai juga menunjukkan sebagian besar berusia 40-60 tahun. ${ }^{13}$

\section{Karakteristik pasien PGK stadium V dengan etiologi nefropati diabetik}

Nefropati diabetik merupakan etiologi terbanyak kedua setelah hipertensi dengan jumlah persentase 27\%. Pada diabetes terjadi peningkatan produk glikosilasi dengan proses non-enzimatik yang disebut AGEs, peningkatan reaksi jalur poliol (polyol pathway), glukotoksisitas, dan protein kinase C memberikan kontribusi pada kerusakan ginjal. Kelainan glomerulus disebabkan oleh denaturasi protein karena tingginya kadar glukosa, hiperglikemia, dan hipertensi intraglomerulus. ${ }^{25}$ 
Pada penelitian ini pasien dengan etiologi nefropati diabetik kebanyakan berjenis kelamin perempuan daripada laki-laki. Hal ini sesuai dengan penelitian Yu tahun 2015 yang menunjukkan pasien diabetes wanita beresiko lebih tinggi terkena PGK. ${ }^{29}$ Namun berbeda dengan studi epidemiologi di Malaysia dan Amerika yang menunjukkan pasien diabetes laki-laki berisiko lebih tinggi terkena PGK daripada perempuan. $^{30}$

Pada penelitian Nur $^{31}$ dan Krishna ${ }^{32}$ mengenai diabetes melitus ditemukan lebih banyak terjadi pada perempuan hal ini dapat disebabkan oleh adanya perbedaan komposisi lemak tubuh dan kadar hormon seksual antara perempuan dan laki-laki dewasa. Pada penelitian sebelumnya oleh Nur tahun 2015 menemukan bahwa persentase nilai HbA1C $\geq 6,5$ cenderung ditemukan pada perempuan. ${ }^{31}$ Perempuan mempunyai peluang lebih besar diakibatkan faktor resiko yang dimiliki lebih banyak seperti peningkatan indeks massa tubuh (IMT) yang lebih besar, sindroma siklus bulanan (premenstrual syndrome), pasca menopause yang membuat distribusi lemak tubuh menjadi mudah terakumulasi akibat proses hormonal tersebut. Selain itu terdapat perbedaan budaya, lingkungan sosial seperti perbedaan dalam perawatan, persepsi penyakit, dan perbedaan secara biologis (hormonal dan genetik). ${ }^{33}$

Pada pasien dengan etiologi DM tipe 2 sering terjadi pada kelompok usia 46-65 tahun. Pada penelitian di Amerika pada 4 tahun penelitian didapatkan pasien PGK dengan Diabetes melitus tipe 2 terbanyak pada usia > 65 tahun $(58,7 \%)$. Seiring bertambahnya usia tubuh mempunyai daya toleransi yang rendah terhadap glukosa. Kondisi ini disebabkan oleh perubahan reseptor glikoprotein yang akan membantu insulin mentransfer glukosa kedalam sel-sel otot, hepar, dan jaringan adiposa mengalami penurunan, akibatnya timbul defisiensi respon terhadap insulin. Semakin lama durasi seseorang menderita diabetes mellitus meningkatkan terjadinya berbagai macam komplikasi baik mikrovaskular maupun makrovaskular. ${ }^{30}$

Pada penelitian sebelumnya yang dilakukan Rini, terdapat empat variabel yang secara statistik berhubungan dengan kejadian DM dengan komplikasi PGK di RSUD DR Soedarso Kota Pontianak, adalah diabetes pada keluarga hipertensi, kebiasaan kurang latihan jasmani atau olahraga, dan dukungan keluarga. ${ }^{34}$

\section{Kesimpulan}

Etiologi PGK stadium V pada pasien rawat inap di RSUD Dokter soedarso tahun 2017-2018 adalah hipertensi, nefropati diabetik, obstruksi saluran kemih, infeksi saluran kemih dan penyakit polikistik ginjal dengan prevalensi etiologi terbanyak yaitu hipertensi dan terbanyak kedua yaitu nefropati diabetik.

\section{Daftar Pustaka}

1. Alwi I, Siti S, Aru WS, Marcellus S, Bambang S, Ari FS. Buku ajar ilmu penyakit dalam. Ed 7. Jakarta : Interna Publishing. 2015; p 2159-97.

2. Fresenius Medical Care SE \& Co. Annual report. [serial on the internet].2017 [cited 2019 Feb 9]; Available from : https: //www.freseniusmedicalcare .com /fileadmin/data/com/pdf/investors/NewsPublications/ Annual Reports/ 2017/ FME Annual Report 2017.pdf

3. Tjekyan RM, Suryadi. Prevalensi dan faktor risiko penyakit ginjal kronik di RSUP Dr. Mohammad Hoesin [skripsi]. Palembang : Universitas Sriwijaya Press. 2014;46(4):275-81.

4. Isro'in L, Cholik HR. Prevalensi faktor risiko gagal ginjal kronik [skripsi] Ponorogo. Universitas Muhammadiyah Ponorogo. 2014; p.24-9.

5. Putri SD, Afgani A, Garina LA. Karakteristik pasin gagal ginjal kronik yang dilakukan hemodialisis di RSUD Al-Ihsan Tahun 2014 [skripsi]. Bandung: Universitas Islam Bandung. 2015; p.570-77.

6. United States Renal Data System. ESRD in the United States. United States; 2015.

7. Kumar V, Abul KA, Jon C. Buku ajar patologi Robbins. 9th ed. Singapura: Elsevier. 2015; p.534-42.

8. Widyastuti R, Butar WRB, Eka B. Korelasi lama menjalani hemodialisis dengan indeks massa tubuh pasien gagal ginjal kronik di RSUD Arifin Achmad Provinsi Riau pada bulan Mei tahun 2014. Jom FK. 2014;1(2):1-12.

9. Alwi I, Simon S, Rudy H, Juferdy K, Dicky LT. Penatalaksanaan di bidang Ilmu Penyakit Dalam: panduan praktik klinis. Jakarta : Interna Publishing. 2012.

10. Salawati L. Analisis lama hemodialisis dengan status gizi penderita penyakit ginjal kronik. J Kedokteran Syiah Kuala. 2012;16(2):64-8.

11. Aggarwal HK, Jain D, Chauda R, Bhatia S, Sehgal R. Assessment of malnutrition inflammation score in different stages of chronic kidney disease. PRILOZI. 2018;39(2-3):51-61

12. Abd ElHafeez S, Bolignano D, D'Arrigo G, Dounousi E, Tripepi G, Zoccali C. Prevalence and burden of chronic kidney disease among the general population and high-risk groups in Africa: a systematic review. BMJ Open. 2018;8(1):15-69.

13. Alalawi F, Ahmed M, AlNour H, Noralla M, Alhadari A. Epidemiology of end-stage renal disease in Dubai: single-center data. Saudi J Kidney Dis Transplant. 2017;28(5):1119-25.

14. Sahid QAU. Hubungan lama diabetes melititus dengan terjadinya gagal ginjal terminal di Rumah Sakit Dokter Moewardi Surakarta [skripsi]. Surakarta : Universitas 
Muhammadiyah Surakarta ; 2012.

15. Pratama AAY. Korelasi lama diabetes melitus terhadap kejadian nefropati diabetik: studi kasus di Rumah Sakit Dokter Kariadi Semarang. J Media Medika Muda; 2013.

16. Nurjanah A. Hubungan antara lama hipertensi dengan angka kejadian gagal ginjal terminal di RSUD dr. Moewardi Surakarta [skripsi]. Surakarta: Universitas Muhammadiyah Surakarta. 2012.

17. Badan Penelitian dan Pengembangan Kesehatan. Hasil utama Riskesdas 2018. Kementerian Kesehatan Republik Indonesia: RISKESDAS; 2018.

18. Dinas Kesehatan Provinsi Kalbar. Laporan surveilans terpadu penyakit. Pontianak: Penerbit Dinas Kesehatan Provinsi Kalbar; 2015.

19. Ratu G, Badji A, Hardjoeno. Profil analisis batu saluran kemih di Laboratorium Patologi Klinik. Indonesian Journal Of Clinical Pathology And Medical Laboratory. 2016;12(3):114-7.

20. Purnomo, BB. Dasar-dasar urologi. Edisi ke-3. Jakarta: CV. Sagung Seto. 2011: h.62-73.

21. Desen W. Buku ajar onkologi klinis. Edisi 2. Jakarta: Badan Penerbit FKUI. 2013; p.476-81.

22. Tjahjodjati, Doddy MS, Rainy U, Basuki BP, Suharto W, Chaidir AM, dkk. Panduan penatalaksanaan klinis pembesaran prostat jinak (benign prostatic hyperplasia/BPH). Jakarta: Ikatan Ahli Urologi Indonesia (IAUI); 2017.

23. National Institute of Diabetes and Digestive and Kidney Diseases. [internet] NIH. 2017 [cited 8 Februari 2019]. Available from : https://www.niddk. nih.gov/health-information/kidneydisease/polycystic kidney-disease.

24. Setiati S, Alwi I, Sudoyo AW, Simadibrata M, Setiyohadi B, Syam AF. Buku ajar Ilmu Penyakit Dalam. Edisi ke-6. Jakarta : Interna Publishing; 2014.

25. Nasri H, Rafieian-Kopaei M. Diabetes mellitus and renal failure: prevention and management. J Res Med Sci Off J Isfahan Univ Med Sci. 2015; 20(11):1112-20.

26. Rizki Fa, Andina M. Karakteristik penderita hipertensi dengan gagal ginjal kronik di Instalasi Penyakit Dalam Rumah Sakit Umum Haji Medan Tahun 2015. 2017;1(1):87-96.

27. Parati G, Ochoa JE, Bilo G, Agarwal R, Covic A, Dekker FW, dkk. Hypertension in chronic kidney disease part 1. 2016;67:1093-101.

28. Hazwan A, Gde NIP. Gambaran karakteristik penderita hipertensi dan tingkat kepatuhan minum obat di wilayah kerja Puskesmas Kintamani I. Intisari Sains Medis. 2017;8(2):130-4.

29. Yu MK, Katon W, Young BA. Associations between sex and incident chronic kidney disease in a prospective diabetic cohort. Nephrology. 2015;20(7):451-8.

30. Wu B, Bell K, Stanford A, Kern DM, Tunceli O, Vupputuri S, et al. Understanding CKD among patients with T2DM: prevalence, temporal trends, and treatment patterns-NHANES 2007-2012. BMJ Open Diabetes Res Care. 2016;4(1):1-11.

31. Ramadan N, Nelly M. Karakteristik penderita diabetes melitus tipe 2 berdasarkan kadar HbA1C di Puskesmas Jaya Baru Kota Banda Aceh. J SEL. 2015;2(2):49-56

32. Sucipto KW, Hendra Z. Karakteristik pasien diabetes melitus tipe-2 pada poliklinik rawat jalan. J Kedokteran Syaih Kuala. 2018;2(2):67-72

33. Chang P-Y, Chien L-N, Lin Y-F, Wu M-S, Chiu W-T, Chiou H-Y. Risk factors of gender for renal progression in patients with early chronic kidney disease: Medicine (Baltimore). 2016;95(30):e4203.

34. Rini S, Suharyo H, Lestariningsih, Heri NHS, Selamat B. Faktor risiko penyakit ginjal kronik diabetes (PGK-DM) pada diabetes mellitus tipe-2 (Studi di RSUD DR Soedarso Kota Pontianak Provinsi Kalimantan Barat). Jurnal Epidemiologi Kesehatan Komunitas. 2018;3(2):101-8. 